\title{
VISUALIZATION OF VITAMIN D-DEPENDENT CALCIUM BINDING PROTEIN IN CHICK INTESTINAL TISSUE BY IMMUNO-SCANNING ELECTRON MICROSCOPY
}

\author{
Setsuko Noda, ${ }^{1}$ Kura Kubota, ${ }^{1}$ Setsuko Yoshizawa, ${ }^{2}$ \\ Sachiko MORIUCHI, ${ }^{2}$ and Norimasa HosOYA ${ }^{2}$ \\ ${ }^{1}$ Department of Anatomy, Tokyo Women's Medical College, \\ Ichigaya, Kawada-cho, Shinjuku-ku, Tokyo 162, Japan \\ ${ }^{2}$ Department of Nutrition, School of Health Sciences, Faculty of Medicine, \\ University of Tokyo, Hongo 7, Bunkyo-ku, Tokyo 113, Japan
}

(Received February 9, 1978)

Vitamin $\mathrm{D}_{3}$ is one of the essential factors in intestinal Ca transport. It is well established that vitamin $\mathrm{D}_{3}$ is first metabolized to a hydroxylated product, 1,25$(\mathrm{OH})_{2} \mathrm{D}_{3}$, before it can act on the process of intestinal Ca transport. $1,25-(\mathrm{OH})_{2} \mathrm{D}_{3}$ is now regarded as a hormone which is secreted from the kidney and is accumulated specifically in the nuclei of the target tissues, such as the intestine, via a specific cytoplasmic receptor for $1,25-(\mathrm{OH})_{2} \mathrm{D}_{3}$. A part of its action mechanism can be elucidated by the stimulation of the synthesis of specific proteins ( 1 ).

With respect to the specific proteins induced by $1,25-(\mathrm{OH})_{2} \mathrm{D}_{3}, \mathrm{CaBP}$ is demonstrated in the intestinal mucosa (2). However, the role of $\mathrm{CaBP}$ in the intestinal $\mathrm{Ca}$ transport is still not clear. The definitive demonstration of intracellular localization of $\mathrm{CaBP}$ is necessary for understanding the role of CaBP. However, regarding the intracellular localization of $\mathrm{CaBP}$, there are some discrepancies among investigators. TAYLOR and WASSERMAN demonstrated histochemically that immunofluorescence indicative of the presence of $\mathrm{CaBP}$ was found in the goblet cells and in association with the surface coat-microvillar region of all intestinal epithelial cells in normal and vitamin D-treated rachitic chicks (3). The other finding is that chick duodenal $\mathrm{CaBP}$ is located neither on microvillar membranes nor in goblet cells, and $\mathrm{CaBP}$ is located rather inside the intestinal epithelial cells (4).

The immuno-scanning electron microscopy technique has been developed for the visualization of antigen exposed to cell surface (5). If CaBP is located on brush borders as reported by TAYLOR and WASSERMAN, this method can be applied to the visualization of $\mathrm{CaBP}$ in the intestine.

Chick $\mathrm{CaBP}$ was purified from vitamin $\mathrm{D}_{3}$ dosed chick duodenal mucosa by a slightly modified method of WASSERMAN et al. (6). The antibody for CaBP was raised

1 野田節子, 久保田く $5,^{2}$ 吉沢節子, 森内幸子, 細谷憲政

To Sachiko MoriUchi all correspondence should be addressed.

Abbreviations: immuno-SEM; immuno-scanning electron microscopy, 1,25- $(\mathrm{OH})_{2} \mathrm{D}_{3} ; 1,25$-dihydroxyvitamin $\mathrm{D}_{3}, \mathrm{CaBP}$; calcium binding protein. 
in rabbit (7). For the observation of CaBP by immuno-SEM, one-day-old chicks were raised on a vitamin D-deficient diet (8) for 5 weeks. Vitamin D-deficient chicks were dosed with either 2,000 IU of vitamin $\mathrm{D}_{3}$ dissolved in $50 \mu \mathrm{l}$ of $95 \%$ ethanol or $50 \mu \mathrm{l}$ of $95 \%$ ethanol intravenously only. After 48 hours, the animals were sacrificed by decapitation and the duodena were used for estimation of CaBP content and immuno-SEM. CaBP content was estimated by radial immunodiffusion as described previously (7). On the other hand, for the immuno-SEM, the duodena were slit open and then fixed for $30 \mathrm{~min}$ at $0{ }^{\circ} \mathrm{C}$ in $10 \%$ formalin in $0.2 \mathrm{M}$ sodium phosphate buffer ( $\mathrm{pH}$ 7.4) either immediately or after being well rinsed with ice-cold $0.2 \mathrm{M}$ sodium phosphate buffer ( $\mathrm{pH}$ 7.4). The fixed tissues were incubated with anti-CaBP rabbit $\gamma$ globulin for 1 hour at room temperature. This was followed by incubation with polystylene latex $(0.6 \mu \mathrm{m}$, Dow Chem. Comp., Indianapolis, USA)-bound antirabbit goat $\gamma$-globulin (Miles Lab., UK) at $4^{\circ} \mathrm{C}$ overnight. Then tissues were fixed with $2.5 \%$ glutaraldehyde and prepared for scanning electron microscopy (5). In this method, polystylene latex is used as a marker of CaBP.

$\mathrm{CaBP}$ content of duodenal mucosa was negligible in vitamin D-deficient chicks, while it was $180 \pm 13.3 \mu \mathrm{g} / \mathrm{g}$ tissue in vitamin $\mathrm{D}_{3}$ dosed chicks. Obviously, CaBP was induced in the duodenal mucosa of vitamin $\mathrm{D}_{3}$ dosed chicks.

Formalin-fixed duodenal tissues not washed by phosphate buffer and incubated with specific anti-CaBP rabbit $\gamma$-globulin and polystylene latex bound goat $\gamma$ globulin, were viewed under a scanning electron microscope at low magnification. This revealed that the duodenal villi showed a large finger-like shape of uniform height. The apices of the goblet cells appeared as depressions within the coat of microvilli or were covered with their secretory substances. The difference between vitamin $\mathrm{D}$-deficient and vitamin $\mathrm{D}_{3}$ dosed chick was not observed in the gross views of the duodenal villi. However, it was faintly noticed that the duodenal villi of vitamin $\mathrm{D}_{3}$ dosed chick were covered with polystylene latex (Fig. 1a, b).

Further examination at higher magnification gave a view of polystylene latex as round small particles. The polystylene latex particles, indicative of the presence of $\mathrm{CaBP}$, were observed on the secretory substances of goblet cells and the microvilli in the vitamin $\mathrm{D}_{3}$ dosed chick duodenum, however, very few in the vitamin D-deficient chicks (Fig. 1c, d).

Fig. 1. Immuno-scanning electron micrograph of duodenal villi from vitamin D-deficient(a, c, e) and vitamin $D_{3}$-treated (b, d, f) chick. Either $50 \mu \mathrm{l}$ of $95 \%$ ethanol or $2,000 \mathrm{IU}$ of vitamin $\mathrm{D}_{3}$ in $50 \mu \mathrm{l}$ of $95 \%$ ethanol was dosed to vitamin D-deficient chicks 48 hours before sacrifice intravenously. Duodena were fixed in $10 \%$ formalin in phosphate buffer ( $\mathrm{pH} \mathrm{7.4)} \mathrm{either}$ immediately (a, b, c, and d) or after being well rinsed with ice-cold phosphate buffer ( $\mathrm{pH} 7.4)(\mathrm{e}$ and $\mathrm{f}$ ), incubated with anti-CaBP rabbit $\gamma$-globulin followed by the incubation with polystylene latex bound anti-rabbit goat $\gamma$-globulin. The tissues were fixed with glutaraldehyde and prepared for the scanning electron microscopy.

a and b: Observation of duodenal villi at low magnification. Black bar denotes $50 \mu \mathrm{m}$.

$\mathrm{c}, \mathrm{d}$, e and f: Observation of duodenal villi at higher magnification. Black bar denotes $1 \mu \mathrm{m}$. The apices of goblet cells (arrows) appeared as depression within the coat of microvilli (M) or were covered with their secretory substances(S). P, denotes polystylene latex particles. 

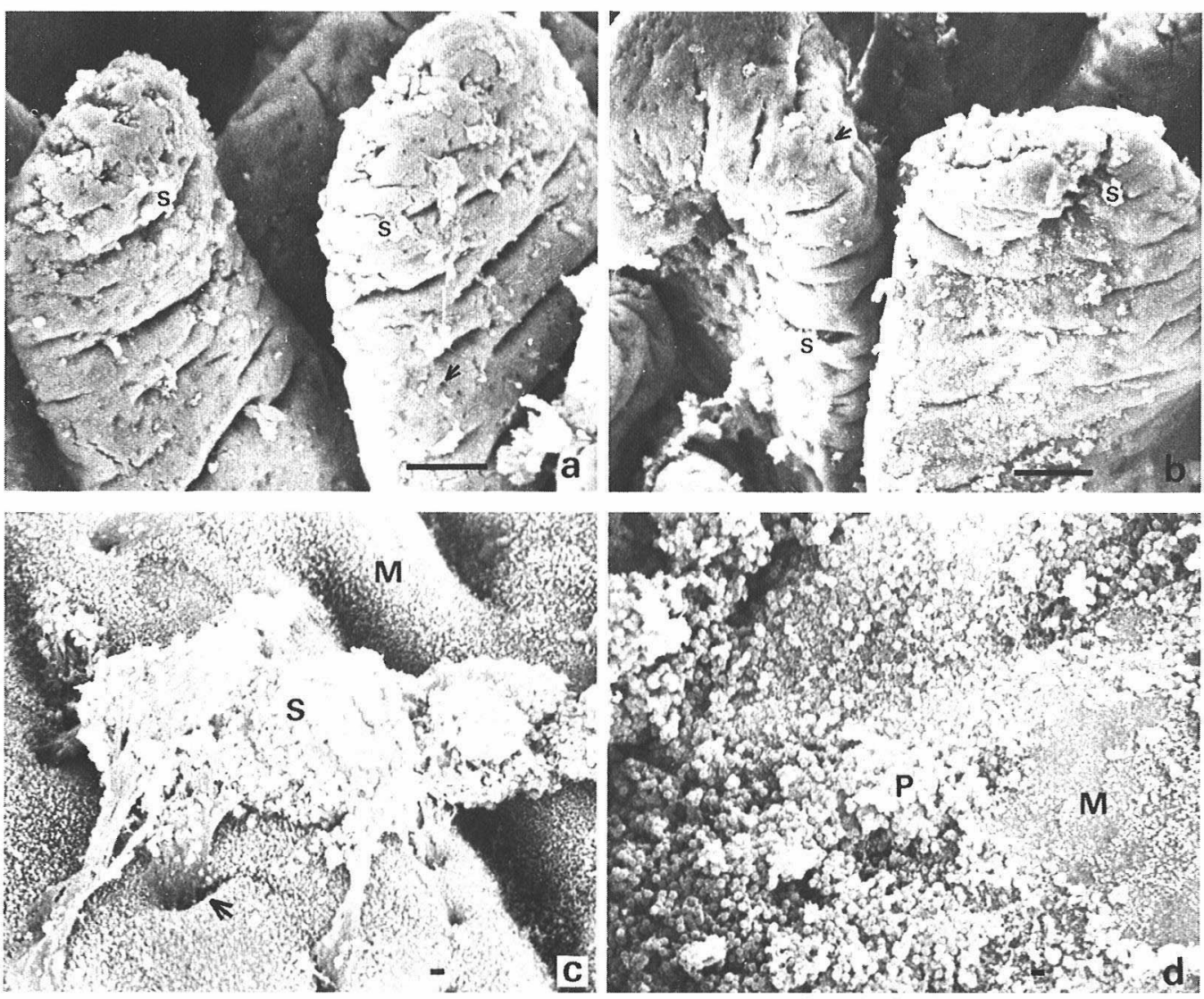

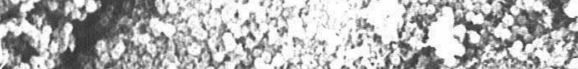

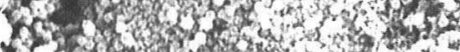
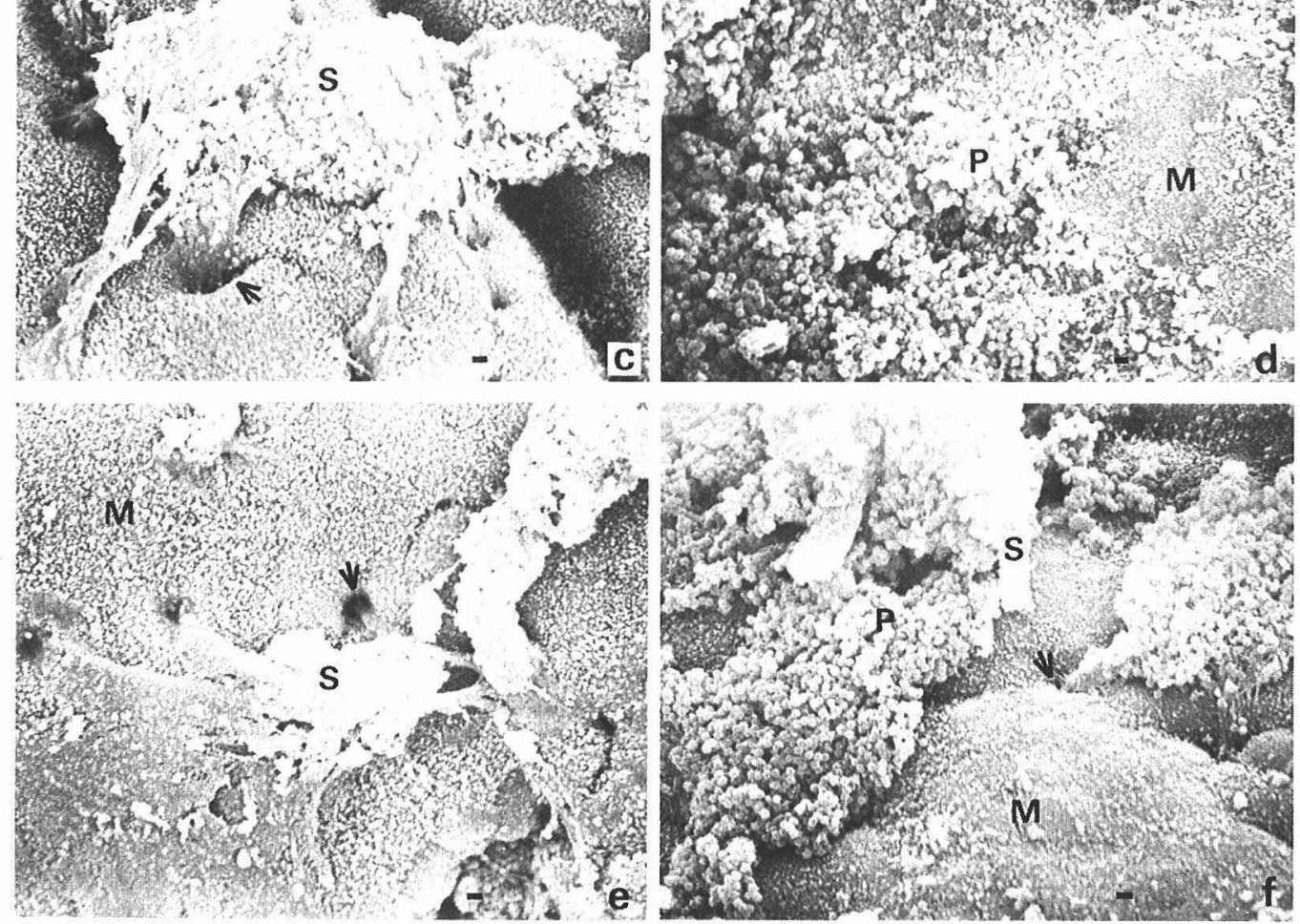

Fig. 1. 
On the other hand, the polystylene latex particles were not observed on the microvilli of vitamin $\mathrm{D}_{3}$ dosed chick when the duodenal surface was well rinsed by phosphate buffer before fixation of tissues. In this case, the polystylene latex particles were only observed on the secretory substances of goblet cells in the vitamin $\mathrm{D}_{3}$ dosed chick duodenal villi (Fig. 1e, f). This suggests that CaBP is contained in the secretory substances of goblet cells and covers the intestinal surface, but it is not integrated into the microvillar membranes.

TAYLOR and WASSERMAN have demonstrated CaBP on the surface coatmicrovillar region of all intestinal epithelial cells in normal and vitamin $\mathrm{D}_{3}$-treated rachitic chick duodenum(3). In their study, tissues were frozen immediately after excising from chick. Then sections were cut using a cryostat microtome. The section was mounted on slide glass, fixed with $95 \%$ ethanol, and then treated with anti-CaBP rabbit $\gamma$-globulin. Namely, the duodenal surface was not rinsed by phosphate buffer before fixation. Therefore, it will be possible that $\mathrm{CaBP}$ demonstrated on the microvilli of vitamin $\mathrm{D}_{3}$-treated chick duodenum by TAYLOR and WASSERMAN could be removed when the duodenal surface was well rinsed by phosphate buffer before freezing.

Immuno-SEM is not suitable for the observation of CaBP inside intestinal epithelial cell. Therefore, we can not comment on the presence of $\mathrm{CaBP}$ inside intestinal epithelial cells from these results, however, it is suggested that CaBP synthesized in goblet cells is secreted into the intestinal lumen and covers the intestinal villi.

We would like to thank Mr. S. Kita (Tokyo Women's Medical College) for his valuable advice concerning immuno-SEM. This work was partly supported by a grant (144027, 377027) from the Scientific Research Fund of the Ministry of Education, Science and Culture of Japan.

\section{REFERENCES}

1) DeLuca, H. F., and Schnoes, H. K. (1976): Metabolism and mechanism of action of vitamin D. Ann. Rev. Biochem., 45, 631-666.

2) Wasserman, R. H., Corradino, R. A., Fullmer, C. S., and Taylor, A. N. (1974): Some aspects of vitamin $\mathrm{D}$ action; calcium absorption and the vitamin D-dependent calcium-binding protein. Vitam. Horm. (New York), 32, 299-324.

3) TAYlor, A. N., and Wasserman, R. H. (1970): Immunofluorescent localization of vitamin Ddependent calcium binding protein. J. Histochem. Cytochem., 18, 107-115.

4) Morrissey, R. L., Zolock, D. T., Bikle, D. D., and Mellick, P. W. (1977): Role of vitamin D dependent calcium binding protein in intestinal calcium absorption. Fed. Proc., 36, 1097.

5) Amano, Y. (1975): Immuno-scanning electron microscopy. The Cell, 7, 80-86.

6) Wasserman, R. H., Corradino, R. A., and Taylor, A. N. (1968): Vitamin D-dependent calcium binding protein: purification and some properties. J. Biol. Chem., 243, 3978-3986.

7) Yoshizawa, S., Moriuchi, S., Shidoji, Y., and Hosoya, N. (1977): Immunological interaction of vitamin D-dependent intestinal calcium-binding protein of chick and rat. Vitamins (in Japanese), 51, 267-273.

8) Omdahl, J., Holick, M., Suda, T., Tanaka, Y., and Deluca, H. F. (1971): Biological activity of 1,25-dihydroxycholecalciferol. Biochemistry, 10, 2935-2940. 